\title{
Diagnostic utility of serum ascites albumin gradient against ascitic fluid total protein for detection of liver disease in patients of ascites- A comparative study
}

\author{
Kansal $A^{1}$, Aharwar $S^{2}$, Trikha $S^{3}$, Sharma $A^{4}$, Sahai $S^{5}$ \\ ${ }^{1}$ Dr Archana Kansal Associate Professor, Department of Medicine, ${ }^{2}$ Dr. Sandeep Aharwar, Assistant Professor \\ Department of Medicine, ${ }^{3}$ Dr Sushma Trikha, Associate Professor, Department of Medicine, ${ }^{4}$ Dr. Ashish Sharma, \\ Resident Department of Medicine, ${ }^{5}$ Dr Shweta Sahai, Assistant Professor, All are affiliated with Department of \\ Medicine, G. R .Medical College, Gwalior, M.P, India.
}

Address for Correspondence: Dr. Sandeep Aharwar sandeepaharwar31@ rediffmail.com

Introduction: Various studies have demonstrated superiority of SAAG (serum ascites albumin gradient) in classifying ascites compared to transudate-exudate concept but with conflicting observations. Ascitic fluid total protein (AFTP) level in ascitic fluid is a much cheaper alternative to the serum ascites albumin gradient ratio. Hence in the study, we have compared the diagnostic accuracy of the old cheaper traditional method against the new method. Methods: Total 102 patients of Ascites were included in the study from J.A. group of hospital, G.R.Medical College (M.P.) in year 2013-15. All medical causes of ascites were included in our study and Non medical causes were excluded. The collected data was analyzed by using Pearson Chi-square statistical analysis to determine correlation between variables. Result: For prediction of liver disease it was found that SAAG was significantly (p value 0.0341) more predictive of Liver disease compared to AFTP. SAAG ( $p$ value $<0.0009$ ) and AFTP ( $p$ value 0.49) were both significant for differentiating cause of ascites when comparison was done between liver and non-liver disease. Conclusion: AFTP is a good surrogate marker for detection of liver disease in ascites. AFTP is an excellent diagnostic test for detection of certain extra hepatic diseases leading to ascites like tubercular peritonitis sub-acute bacterial peritonitis and anaemia-hypo-proteinemia.

Keywords: Serum Ascites Albumin gradient, Albumin, Total Protein

\section{Introduction}

Ascites is one of the most common amongst the various clinical problems confronting a physician, and ascitic fluid analysis is the most effective way to diagnose it. The traditional classification of ascites into 'exudative' and 'transudative' involves estimation of ascitic fluid total protein (AFTP), which is high $\geq 2.5 \mathrm{gm} / \mathrm{dL}$ in exudate and $<2.5 \mathrm{gm} / \mathrm{dL}$ in transudate [1]. This classification, however, is unable to correctly identify the aetiological factors responsible for its causation and has been challenged on various occasions in different clinical conditions [2, 3]. Moreover, it offers little insight to the pathophysiology of ascitic fluid formation [4].

These drawbacks led to the development of a new approach to classify ascites, based on albumin gradient between plasma and ascites. Albumin being the single

Manuscript received: $11^{\text {th }}$ Aug 2015

Reviewed: $17^{\text {th }}$ Aug 2015

Author Corrected: $29^{\text {th }}$ Aug 2015

Accepted for Publication: $9^{\text {th }}$ Sept 2015 most important factor of oncotic pressure generation, the difference between the serum and ascitic albumin concentration (serum/ascites albumin gradient -SAAG) was used to differentiate ascitic fluid into categories : gradient $\geq 1.1 \mathrm{~g} / \mathrm{dl}$ in cases with portal hypertension and $<1.1 \mathrm{~g} / \mathrm{dl}$ in ascites unrelated to portal hypertension [4, 5]. Various studies have demonstrated superiority of SAAG in classifying ascites compared to transudateexudate concept but with conflicting observations [6-8]. There have also been reports arguing against superiority of SAAG compared with other markers used for differentiation of ascites into transudate and exudate especially in non-alcoholic liver disease [9].

Ascitic fluid total protein level in ascitic fluid is a much cheaper alternative to the serum ascites albumin gradient ratio. Hence in the study, we have planned to compare the diagnostic accuracy of the old cheaper traditional method against the new method. 


\section{Aims and Objectives}

- To compare the efficacy of AFTP (Ascitic Fluid Total Protein) against the gold standard method of SAAG ratio for diagnosing the cause of ascites.

- To find out the diagnostic efficacy of AFTP for various diseases which may cause ascites e.g. tubercular ascites or subacute baceterial peritonitis

\section{Methods}

Total 102 patients of Ascites were included in the study from J.A. group of hospital, G.R.Medical College (M.P.) in year 2013-15

\section{Results}

Table No 1: Demographic distribution

\begin{tabular}{|l|l|}
\hline Age groups (yrs) & No. of patients $(\mathbf{n = 1 0 2})$ \\
\hline $18-29$ & $8(7.8 \%)$ \\
\hline $30-49$ & $54(52.94 \%)$ \\
\hline $50-69$ & $31(30.39 \%)$ \\
\hline$>70$ & $9(8.8 \%)$ \\
\hline Sex & No. of patients $(\mathbf{n}=\mathbf{1 0 2})$ \\
\hline Male & $69(67.64 \%)$ \\
\hline Female & $33(32.3 \%)$ \\
\hline
\end{tabular}

We found most no. of cases in age group 30-49 years that accounts for 52.94\% out of 102 patient and most of our patients were males $(67.64 \%)$ as compared to females $(32.3 \%)$.

Table No 2: Disease wise distribution

\begin{tabular}{|l|l|}
\hline Disease & No. of patients(n=102) \\
\hline Liver Disease & $71(69.60 \%)$ \\
\hline Liver Disease With SBP & $6(5.8 \%)$ \\
\hline Tuberculosis Of Abdomen & $18(17.6 \%)$ \\
\hline Anaemia Hypoproteinemia & $5(4.9 \%)$ \\
\hline Nephrogenic & $4(3.92 \%)$ \\
\hline Cardiogenic & $2(1.96 \%)$ \\
\hline Malignancy & $1(0.98 \%)$ \\
\hline Pyoperitoneum & $1(0.98 \%)$ \\
\hline
\end{tabular}

As per table no 2 most cases of Ascites were of liver disease (69.60\%) followed by TB abdomen (18\%) and rest were other diseases.

Table No. 3: Occurrence of diseases according to age

\begin{tabular}{|l|l|l|l|l|}
\hline \multirow{2}{*}{ Disease } & Age groups (in years) & \multicolumn{5}{|l|}{ (70 } \\
\cline { 2 - 5 } & $\mathbf{1 8 - 2 9}$ & $\mathbf{3 0 - 4 9}$ & $\mathbf{5 0 - 6 9}$ & $4(4.2 \%)$ \\
\hline Liver disease(71) & $3(4.2 \%)$ & $41(57.7 \%)$ & $23(32.0 \%)$ & $3(15.7 \%)$ \\
\hline Tubercular peritonitis(18) & $2(11.1 \%)$ & $7(38.8 \%)$ & $6(33.33 \%)$ & $1(25 \%)$ \\
\hline Nephrogenic (4) & 0 & $3(75 \%)$ & 0 & 0 \\
\hline
\end{tabular}

\section{Exclusion criteria}

2) Pregnancy, hemodynamic instability, bleeding disorders and other medical contraindication to perform upper GI endoscopy

The collected data was analyzed by using Pearson Chisquare statistical analysis to determine correlation between variables. 


\begin{tabular}{|l|l|l|l|l|}
\hline Anemia and hypoprotienemia (5) & $1(20 \%)$ & $2(40 \%)$ & 0 & $2(40 \%)$ \\
\hline Cardiogenic (2) & 0 & $1(50 \%)$ & $1(50 \%)$ & 0 \\
\hline Malignancy (1) & 0 & 0 & 0 & $1(100 \%)$ \\
\hline Pyoperitoneum (1) & $1(100 \%)$ & 0 & 0 & 0 \\
\hline
\end{tabular}

Most of the diseases were found in middle age group except malignancy which was more common in older age group (>70 years).

Table No. 4: Comparison between SAAG and AFTP in various diseases

\begin{tabular}{|l|l|l|l|l|l|}
\hline \multirow{2}{*}{ Disease } & AFTP & \multicolumn{2}{l|}{ SAAG } & P value \\
\cline { 2 - 6 } & $\mathbf{2 . 5}$ & $\mathbf{2 . 5}$ & $\leq \mathbf{1 . 1}$ & $\mathbf{1 . 1}$ \\
\hline Liver Disease $(\mathrm{n}=71)$ & $40(56.33 \%)$ & $31(43.65 \%)$ & $16(22.53 \%)$ & $55(77.46 \%)$ & $.0341^{*}$ \\
\hline $\begin{array}{l}\text { Tuberculosis of Abdomen } \\
(\mathrm{n}=18)\end{array}$ & $6(33.33 \%)$ & $12(66.67 \%)$ & $13(72.22 \%)$ & $5(27.77 \%)$ & 0.479 \\
\hline $\begin{array}{l}\text { Anaemia with Hypoprotienemia } \\
(\mathrm{n}=5)\end{array}$ & $2(40 \%)$ & $3(60 \%)$ & $3(60 \%)$ & $2(40 \%)$ & $.0072^{* *}$ \\
\hline Nephrogenic $(\mathrm{n}=4)$ & & & & \\
\hline Cardiogenic $(\mathrm{n}=2)$ & $3(75 \%)$ & $1(25 \%)$ & $3(75 \%)$ & $1(25 \%)$ & 0.862 \\
\hline Malignancy $(\mathrm{n}=1)$ & $2(100 \%)$ & 0 & $1(50 \%)$ & $1(50 \%)$ & $<.0001^{* *}$ \\
\hline Pyoperitoneum $(\mathrm{n}=1)$ & $1(100 \%)$ & 0 & 0 & $1(100 \%)$ & $<.0001^{* *}$ \\
\hline
\end{tabular}

** highly significant

*significant

On comparison between SAAG and AFTP, test of significance was performed individually for each disease with the help of Chi square and student ' $\mathrm{T}$ ' test. For prediction of liver disease it was found that SAAG was significantly more predictive of Liver disease compared to AFTP.

1. Chi square value is $4.49 \mathrm{p}$ value is $.0341^{*}$ in case of liver disease i.e significant.

2. Chi square value is $0.5, \mathrm{p}$ value is .4795 in case tubercular peritonitis is Insignificant.

3. Chi square value is $=7.22$, $\mathrm{p}$ value is $.0072 * *$, highly significant, in anemia and hypoproteinemia.,

4. Chi square value is 0.03 , p value is 0.862 is insignificant, in nephrogenic ascites.

5. Chi square value is $=64.3, \mathrm{p}$ value is $<.0001^{* *}$, highly significant, in cardigenic ascites.

6. Chi square value is=Infinity, $\mathrm{p}$ value is. $<.0001^{* *}$, highly significant, in malignancy.

7. Chi square value is $=64.3$, $\mathrm{p}$ value is $<.0001^{* *}$, highly significant in pyoperitoneum.

Table No. 5: Comparison between SAAG and AFTP in liver and non liver disease (Frequency table)

\begin{tabular}{|l|l|l|l|l|}
\hline \multirow{2}{*}{ Disease } & AFTP & \multicolumn{1}{l|}{ SAAG } \\
\cline { 2 - 5 } & $<\mathbf{2 . 5}$ & $\mathbf{2} \mathbf{2 . 5}$ & & $<\mathbf{2 . 5}$ \\
\hline Liver Disease(71) & $40(56.33 \%)$ & $31(43.65 \%)$ & $16(22.53 \%)$ & $55(77.46 \%)$ \\
\hline Non liver disease(31) & $15(48.38 \%)$ & $16(51.61 \%)$ & $20(64.51 \%)$ & $11(35.48 \%)$ \\
\hline
\end{tabular}

Chi square value is 7.13,p value is.0076 i.e. highly significant while detecting a case of hepatic disease over extrahepatic disease with the help of SAAG.

Table No. 6 : Comparison between SAAG and AFTP in liver disease and non-liver disease

\begin{tabular}{|c|c|c|c|c|c|c|c|c|}
\hline Test & $\begin{array}{l}\text { Liver } \\
\text { disease } \\
\text { Mean } \pm \text { SD }\end{array}$ & $\begin{array}{l}\text { Non liver } \\
\text { disease } \\
\text { Mean } \pm \text { SD }\end{array}$ & $\begin{array}{l}\text { P value } \\
(<.005 \text { is } \\
\text { significant })\end{array}$ & : & : & $\vec{a}$ & $\vec{z}$ & 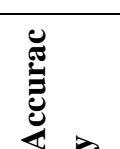 \\
\hline SAAG & $1.62 \pm 0.75$ & $1.12 \pm 0.66$ & 0.0009 & $77.46 \%$ & $64.52 \%$ & $83.33 \%$ & $55.56 \%$ & $73.52 \%$ \\
\hline AFTP & $2.92 \pm 10.96$ & $2.54 \pm 1.15$ & .049 & $56.3 \%$ & $51.6 \%$ & $72.72 \%$ & $34 \%$ & $54.9 \%$ \\
\hline
\end{tabular}


In a table 7, comparison was done between the mean values of SAAG and AFTP for differentiating liver disease and non liver disease. SAAG and AFTP were both significant for differentiating cause of ascites.

\section{Discussion}

According to the Starling hypothesis the fluid movement across a capillary membrane is controlled by the balance of hydrostatic and colloid osmotic pressure [10]. Forces tend to achieve a dynamic equilibrium such that increased portal pressure is counter balanced by increased oncotic pressure gradients, the effective gradient between serum and interstitial or ascitic fluid absolute oncotic pressure. When portal pressure is not increased, ascites formation occurs in the presence of an oncotic gradient that is not increased. Since albumin is the main determinant of oncotic pressure, we measured the serum ascites gradient of albumin concentration as a reflection of portal hypertension in the genesis of ascites from various causes.

Our study is similar to the study by Bibhuti Das [11] with respect to sex distribution, males were $(70 \%)$ and females were $(30 \%)$, in our study males were $(67.64 \%)$ and females were $(32.3 \%)$.

Al-Knawy et al [12] studied etiology of ascites and diagnostic value of serum ascites albumin gradient in non-alcohol liver disease found SAAG accuracy was $91 \%$, PPV was $80 \%$, NPV $98 \%$. AFTP accuracy was 84 , PPV was $68 \%$ and NPV was $96 \%$

Muhammad Younas et al [13] studied role of serumascites albumin gradient in differential diagnosis of ascites found SAAG accuracy $96 \%$, sensitivity $97 \%$, specificity 95\%, PPV $98.6 \%$ and NPV was $90 \%$. In AFTP accuracy 56\%, sensitivity 53\%, specificity $70 \%$, PPV $86 \%$ and NPV $29 \%$.

In our study the accuracy $73.5 \%$, sensitivity $77.4 \%$, specificity $64.3 \%$, positive predictive value $33.3 \%$, and negative predictive value $55.5 \%$. of SAAG were comparatively less than other studies.

On consideration of AFTP the accuracy 54.9\%, sensitivity $56.3 \%$, specificity $51.6 \%$, and positive predictive value $72.7 \%$, and negative predictive value $34 \%$ matched with other studies.

Our findings were closest to Das BB et al [11] and Muhammad Yunus et al [13].

In present study there is significant correlation with
SAAG and development of ascites because of alcoholic liver disease. No strong correlation was present with non alcoholic liver disease. These findings are comparable with the study of Alkanway et al [12], which concluded that, in cases of low SAAG, after exclusion of causes like peritoneal tuberculosis, carcinoma, pancreatitis, nephrotic syndrome and biliary ascites, one should consider non alcoholic liver disease.

\section{Summary}

When confronted with a patient of ascites, it is a diagnostic challenge to find out whether the ascites is of hepatic or extra hepatic origin. Previous studies have well established the role of SAAG as a prediction of cirrhosis of liver. In this study we attempted to correlate the prediction value of AFTP for differentiating between hepatic and extra hepatic ascites. We found that SAAG remains a very accurate tool for predicting liver disease in presence of ascites. However, the values of AFTP correlated with SAAG and were quite helpful in predicting the presence of liver disease in ascites and may be used as a surrogate marker instead of SAAG in settings where SAAG is not feasible due to technical or economic issues. AFTP was found to be an excellent predictor for the diagnosis of diseases like tubercular peritonitis, Sub acute bacterial peritonitis, anaemia, hypo-proteinemia. In facts, its diagnostic accuracy was superior when compared to SAAG.

\section{Conclusions}

- AFTP is a good surrogate marker for detection of liver disease in ascites.

- AFTP is an excellent diagnostic test for detection of certain extra hepatic diseases leading to ascites like tubercular peritonitis sub-acute bacterial peritonitis and anaemia-hypo-proteinemia.

\section{Funding: Nil \\ Conflict of interest: None.}

Permission of IRB: Yes

\section{References}

1. Rovelstad RA, Bartholomew LG, C, Mckenzie $\mathrm{BF}, \mathrm{H}$. Ascites. I. The value of examination of ascitic fluid and blood for lipids and for proteins by electrophoresis. Gastroenterology. 1958 Mar;34(3):43651. 
2. Sampliner

RE, Iber

FL.

High protein ascites in patients with uncomplicated hep atic cirrhosis. Am J Med Sci. 1974 May;267(5):275-9.

3.RectorWG Jr, Reynolds TB. Superiority of the serum ascites albumin difference over the ascites total protein concentration in separation of "transudative" and "exudative" ascites. Am J Med. 1984 Jul;77(1):83-5.

4. Rector WG Jr. An improved diagnostic approach to ascites. Arch Intern Med. 1987 Feb;147(2):215.

5. Paré P, Talbot J, Hoefs JC. Serumascites albumin concentration gradient:

a physiologic approach to the differential diagnosis of ascites.Gastroenterology. 1983 Aug;85(2): 240-4.

6. Runyon BA, Montano AA, Akriviadis EA, Antillon MR, Irving MA, McHutchison JG. The serumascites albumin gradient is superior to the exudatetransudate concept in the differential diagnosis ofascites. Ann Intern Med. 1992 Aug $1 ; 117(3): 215-20$.

7. Goyal AK, Goyal SK, Pokharna DS, Sharma SK. Differential diagnosis of ascitic fluid : Evaluation and comparison of various biochemical criteria with a special reference to serum ascites albumin concentration gradient and its relation to portal pressure. Tropical Gastroenterology 1989 Jan-Mar; 10 (1): 51-5.

8. Gupta R, Misra SP, Dwivedi M et al. Diagnostic ascites :Value of total protein albumin, cholesterol their ratios serum ascites albumin and cholesterol gradient. J Gastroenterology Hepatology 1995 May-Jun; 10 (3): 295-9.

9. Kajani MA, Yoo YK, Alexander JA, Gavaler JS, Stauber RE, Dindzans VJ, Van Thiel DH. Serum ascites albumin gradients in nonalcoholic liver disease. Dig Dis Sci. 1990 Jan;35(1):33-7.

10. Starling EH. On the Absorption of Fluids from the Connective Tissue Spaces. J Physiol. 1896 May 5;19(4):312-26.

11. Das B, Acharya U, Purohit A. Comparative utility of sero ascites albumin gradient and ascitic fluid total protein for differential diagnosis of ascites. Indian Pediatr. 1998 Jun;35(6):542-5.

12. Al-Knawy BA. Etiology of ascites and the diagnostic value of serum-ascites albumin gradient in non-alcohol liver disease. Ann Saudi Med. 1997 Jan;17(1):26-8.

13. Younas M, Sattar A, Hashim R, Ijaz A, Dilawar M, Manzoor SM, Ali A, Khan FA. Role of serumascites albumin gradient in differential

diagnosis of ascites. J Ayub Med Coll Abbottabad. 2012 Jul-Dec;24(3-4):97-9.

\section{How to cite this article?}

Kansal A, Aharwar S, Trikha S, Sharma A, Sahai S. Diagnostic utility of serum ascites albumin gradient against ascitic fluid total protein for detection of liver disease in patients of ascites- A comparative study. Int J Med Res Rev 2015;3(8):861-865. doi: 10.17511/ijmrr.2015.i8.162. 